\title{
Short tandem repeat (STR) based genetic diversity and relationship of indigenous Niger cattle
}

\author{
Moustapha Grema $^{1,2}$, Amadou Traoré ${ }^{3,5}$, Moumouni Issa ${ }^{1}$, Marichatou Hamani ${ }^{1}$, Maaouia Abdou ${ }^{1}$, \\ Albert Soudré ${ }^{4}$, Moumouni Sanou ${ }^{3,5}$, Rudolf Pichler ${ }^{5}$, Hamidou H. Tamboura ${ }^{3}$, Yenikoye Alhassane ${ }^{1}$, \\ and Kathiravan Periasamy ${ }^{5}$ \\ ${ }^{1}$ Faculté des sciences et techniques, Abdou Moumouni University, BP 10960, Niamey, Niger \\ ${ }^{2}$ Faculté des Sciences Agronomiques, Diffa University, BP 78, Diffa, Niger \\ ${ }^{3}$ Institut de l'Environnement et de Recherches Agricoles (INERA), Laboratoire de Biologie et santés animales, \\ 04 BP 8645, Ouagadougou 04, Burkina Faso \\ ${ }^{4}$ Ecole Normale Supérieure, University of Koudougou, BP 376, Koudougou, Burkina Faso \\ ${ }^{5}$ Animal Production and Health Laboratory, Joint FAO/IAEA Division, International Atomic Energy Agency, \\ Vienna, Austria
}

Correspondence to: Kathiravan Periasamy (kathirvet@yahoo.co.in)

Received: 26 February 2017 - Revised: 20 July 2017 - Accepted: 21 September 2017 - Published: 14 November 2017

\begin{abstract}
The diversity of cattle in Niger is predominantly represented by three indigenous breeds: Zebu Arabe, Zebu Bororo and Kuri. This study aimed at characterizing the genetic diversity and relationship of Niger cattle breeds using short tandem repeat (STR) marker variations. A total of 105 cattle from all three breeds were genotyped at 27 STR loci. High levels of allelic and gene diversity were observed with an overall mean of 8.7 and 0.724 respectively. The mean inbreeding estimate within breeds was found to be moderate with 0.024 , 0.043 and 0.044 in Zebu Arabe, Zebu Bororo and Kuri cattle respectively. The global $F$ statistics showed low genetic differentiation among Niger cattle with about $2.6 \%$ of total variation being attributed to between-breed differences. Neighbor-joining tree derived from pairwise allele sharing distance revealed Zebu Arabe and Kuri clustering together while Zebu Bororo appeared to be relatively distinct from the other two breeds. High levels of admixture were evident from the distribution of pairwise inter-individual allele sharing distances that showed individuals across populations being more related than individuals within populations. Individuals were assigned to their respective source populations based on STR genotypes, and the percent correct assignment of Zebu Bororo (87.5 to $93.8 \%$ ) was consistently higher than Zebu Arabe (59.3 to $70.4 \%$ ) and Kuri (80.0 to $83.3 \%$ ) cattle. The qualitative and quantitative tests for mutation drift equilibrium revealed absence of genetic bottleneck events in Niger cattle in the recent past. High genetic diversity and poor genetic structure among indigenous cattle breeds of Niger might be due to historic zebu-taurine admixture and ongoing breeding practices in the region. The results of the present study are expected to help in formulating effective strategies for conservation and genetic improvement of indigenous Niger cattle breeds.
\end{abstract}

\section{Introduction}

Niger is a landlocked sub-Saharan country in West Africa that primarily depends on agriculture and livestock. The livestock sector contributes about $40 \%$ of the country's agricultural gross domestic product (GDP) and $14 \%$ of the national GDP (Apaa-Okello et al., 2015). The rural livelihood is essentially dependent on livestock with four out of every five households rearing animals. Each of these households owns about 2.8 Tropical Livestock Units (TLU) that are predominantly made up of cattle $(55 \%)$ and small ruminants $(33 \%)$ (World Bank, 2012). Cattle in Niger not only play a vital role in rural subsistence but also possess significant cultural importance, particularly during the performance of religious rites and celebrations. The cattle population in Niger num- 
bers around 11.4 million (FAOSTAT, 2014) and forms part of the primary non-mineral exports from the country. Most of these cattle belong to indigenous breeds/populations that are well adapted to survive and reproduce under harsh Sahelian conditions, often affected by varied rainfall and drought (Okomo-Adhiambo, 2002). Documentation of these native breeds has been mostly limited to physical or zootechnic characteristics with little or no information available on their genetic and production performance characteristics.

Indigenous cattle of Niger include zebu breeds like Azawak, Bororo, Djelli/Arabe and Goudali as well as a taurine population called Kuri. Kuri (also known as the Baharie, Bare, Borrie, Boudouma, Dongolé, Koubouri, Buduma) is a large-bodied humpless longhorn cattle whose exact historical origin is unknown (Blench, 1993; Meghen et al., 2000). These cattle are distributed in the region of Lake Chad and along its eastern shores. Kuri cattle has distinctive, inflated, spongy horns with a mean height of $1.5 \mathrm{~m}$ at withers and an average estimated body weight of about $550 \mathrm{~kg}$. Kuri are one of the largest breeds of African cattle and are noted for their extremely variable coat color pattern, meat and milk production potentials and ability to thrive under semi-aquatic conditions. The breed is well adapted to the semi-aquatic environment of Lake Chad such that it is unable to survive elsewhere. Kuri cattle is currently classified under the category threatened by extinction.

Bororo, also called Red Fulani, Red Bororo, Wodabe, Fellata, Foulata, Abori, Bodadi, Brahaza and Djafoun, are one of the largest zebu breeds in West Africa. They are distinguished by deep burgundy colored coat, pendulous ears and long, thick lyre-shaped horns that can extend up to 120 $140 \mathrm{~cm}$. These are temperamental, intractable cattle suitable to arid and semi-arid regions, but are poor milkers. They are perfectly adapted to long marches and are therefore well suitable for transhumant pastoral systems. At birth, both male and female calves weigh between 15 and $20 \mathrm{~kg}$ and, under natural conditions, the adult weight ranges from 400 to $500 \mathrm{~kg}$ for males and 350 to $450 \mathrm{~kg}$ for females. Weights vary widely according to the seasonal availability and quality of fodder in the region. In Niger, Zebu Bororo is mainly located in the southern part of the country, particularly in Dosso, Tahoua, Maradi and Diffa regions. Around Diffa, Bororo cattle are distributed together with the taurine type Kuri cattle. Zebu Arabe cattle (known as Arab Shuwa, Arab Choa or Wadera) are also located in the area surrounding Lake Chad overlapping the habitat of Kuri cattle. They are mediumsized and lightly built animals. They usually possess dark red, black, pied or brown coat color with or without small white patches on the underline. Zebu Arabe are short-horned cattle and have a small erect hump. The ears are long but not pendulous with short, moderately thick, round or flat horns. Their usefulness under stressful environment has been well recognized; the animals are considered to be good dairy animals and used by women for riding and as pack animals. Information on genetic diversity and relationship among in- digenous cattle of Niger is very limited. Genetic diversity is an essential component in the fitness of a population, for it to survive and adapt to the changing environmental conditions. Molecular characterization of indigenous breeds is the primary step in formulating and optimizing strategies for conservation and genetic improvement, to increase productivity as well as meeting future market demands. The present study was undertaken to evaluate genetic diversity of three Niger cattle breeds/populations (Kuri, Zebu Bororo and Zebu Arabe) and to assess their genetic relationship using multilocus short tandem repeat data.

\section{Materials and methods}

\subsection{Sampling and STR genotyping}

A total of 105 individuals belonging to three Niger cattle breeds, two Zebus (Arabe and Bororo) and one taurine (Kuri) were sampled. The sampling site included shores and islands of Lake Chad situated at the east of the arid Sahel agroecological region between $12^{\circ} 20^{\prime}-14^{\circ} 20^{\prime} \mathrm{N}$ latitude and 13 $15^{\circ} 30^{\prime} \mathrm{E}$ longitude and bordered by Cameroon, Chad and Nigeria. The numbers of animals sampled for each of the three cattle breeds were as follows: Zebu Arabe (27), Zebu Bororo (48) and Kuri (30). The farmers were interviewed in detail to ensure the unrelatedness of sampled cattle. Blood samples were collected after jugular venipuncture in EDTA coated Vacutainer tubes, and DNA was extracted from whole blood using MasterPure DNA Purification Kit (Biozym, Illumina Inc, USA). DNA samples were then stored at $4{ }^{\circ} \mathrm{C}$ until PCR amplification and genotyping. 27 FAO-recommended short tandem repeat (STR) markers (FAO, 2011) with forward primers conjugated to one of the three fluorescent dyes (FAM, HEX and ATTO550) were used for diversity analysis. Polymerase chain reaction was performed under the following conditions: initial denaturation for $5 \mathrm{~min}$ at $95^{\circ} \mathrm{C}$, followed by 35 cycles of denaturation at $95^{\circ} \mathrm{C}$ for $30 \mathrm{~s}$, annealing at respective temperature of each marker locus for $1 \mathrm{~min}$, elongation at $72{ }^{\circ} \mathrm{C}$ for $1 \mathrm{~min}$ with a final extension at $72^{\circ} \mathrm{C}$ for $10 \mathrm{~min}$. The PCR products were then electrophoresed after multiplexing in an automated DNA analyzer ABI3100 (Applied Biosystems, USA) with ROX500 (Applied Biosystems, USA) as an internal lane control. All 27 STR loci were multiplexed in six sets for genotyping, as shown in Table 1. The allele size data for each sample were then extracted using GeneMapper v.4.1 software (Applied Biosystems, USA).

\subsection{Statistical analysis of STR data}

The presence of null alleles in the dataset was checked using MicroChecker version 2.2.3 (Oosterhout et al., 2004). Basic diversity indices like observed number of alleles, observed and expected heterozygosity, pairwise and global $F$ statistics were calculated using Microsatellite Analyzer (MSA) version 3.15 (Dieringer and Schlötterer, 2003). The effective 
Table 1. Details of microsatellite loci and allelic diversity in Zebu Arabe, Zebu Bororo and Kuri breeds of Niger cattle.

\begin{tabular}{|c|c|c|c|c|c|c|c|c|c|c|}
\hline \multirow[t]{2}{*}{ Locus } & \multirow{2}{*}{$\begin{array}{l}\text { Multiplex } \\
\text { panel }\end{array}$} & \multirow{2}{*}{$\begin{array}{l}\text { Anneal } \\
\text { temp. }\end{array}$} & \multirow[t]{2}{*}{ Dye } & \multirow{2}{*}{$\begin{array}{r}\text { Allele size } \\
\text { range }\end{array}$} & \multicolumn{2}{|c|}{ Zebu Arabe } & \multicolumn{2}{|c|}{ Zebu Bororo } & \multicolumn{2}{|c|}{ Kuri } \\
\hline & & & & & $n_{\mathrm{a}}$ & $n_{\mathrm{e}}$ & $n_{\mathrm{a}}$ & $n_{\mathrm{e}}$ & $n_{\mathrm{a}}$ & $n_{\mathrm{e}}$ \\
\hline CSRM60 & 1 & $60^{\circ} \mathrm{C}$ & FAM & $87-109$ & 10 & 3.83 & 10 & 2.65 & 7 & 3.64 \\
\hline CSSM66 & 1 & $60^{\circ} \mathrm{C}$ & FAM & $177-197$ & 9 & 6.47 & 10 & 6.32 & 8 & 4.77 \\
\hline HEL1 & 1 & $56^{\circ} \mathrm{C}$ & HEX & $96-114$ & 5 & 3.24 & 5 & 3.04 & 8 & 3.53 \\
\hline INRA63 & 1 & $56^{\circ} \mathrm{C}$ & HEX & $173-183$ & 4 & 1.85 & 4 & 2.02 & 5 & 2.57 \\
\hline BM1824 & 2 & $61{ }^{\circ} \mathrm{C}$ & ATTO550 & $183-197$ & 4 & 3.54 & 4 & 3.79 & 4 & 2.48 \\
\hline ETH152 & 2 & $60^{\circ} \mathrm{C}$ & FAM & 189-199 & 6 & 2.31 & 6 & 2.39 & 4 & 2.24 \\
\hline HAUT27 & 2 & $54{ }^{\circ} \mathrm{C}$ & HEX & $140-150$ & 4 & 2.76 & 6 & 3.74 & 4 & 2.62 \\
\hline INRA05 & 2 & $54{ }^{\circ} \mathrm{C}$ & FAM & $134-148$ & 6 & 2.96 & 4 & 2.16 & 5 & 2.70 \\
\hline BM1818 & 3 & $60^{\circ} \mathrm{C}$ & HEX & $256-272$ & 7 & 4.89 & 8 & 3.96 & 7 & 4.36 \\
\hline ETH3 & 3 & $63^{\circ} \mathrm{C}$ & FAM & $99-125$ & 6 & 3.09 & 7 & 1.86 & 5 & 2.86 \\
\hline HEL9 & 3 & $56^{\circ} \mathrm{C}$ & ATTO550 & $155-175$ & 11 & 7.11 & 10 & 6.49 & 9 & 6.44 \\
\hline ILSTS006 & 3 & $54^{\circ} \mathrm{C}$ & FAM & $284-300$ & 7 & 3.50 & 8 & 3.38 & 7 & 2.60 \\
\hline TGLA53 & 3 & $55^{\circ} \mathrm{C}$ & HEX & $153-187$ & 14 & 4.92 & 14 & 4.56 & 11 & 5.86 \\
\hline HAUT24 & 4 & $53^{\circ} \mathrm{C}$ & HEX & $103-125$ & 7 & 5.81 & 8 & 4.12 & 6 & 4.56 \\
\hline HEL5 & 4 & $54^{\circ} \mathrm{C}$ & FAM & $148-164$ & 5 & 3.35 & 7 & 4.75 & 7 & 3.97 \\
\hline INRA032 & 4 & $56^{\circ} \mathrm{C}$ & ATTO550 & 164-208 & 8 & 6.13 & 7 & 5.34 & 7 & 4.23 \\
\hline SPS115 & 4 & $61^{\circ} \mathrm{C}$ & FAM & $243-255$ & 5 & 2.34 & 6 & 1.79 & 7 & 2.39 \\
\hline ETH185 & 5 & $65^{\circ} \mathrm{C}$ & ATTO550 & $224-252$ & 9 & 4.88 & 11 & 2.97 & 8 & 3.73 \\
\hline HEL13 & 5 & $54^{\circ} \mathrm{C}$ & HEX & 176-194 & 6 & 3.85 & 5 & 3.13 & 6 & 3.99 \\
\hline ILSTS05 & 5 & $56^{\circ} \mathrm{C}$ & FAM & $178-190$ & 5 & 3.37 & 5 & 3.76 & 5 & 3.61 \\
\hline INRA035 & 5 & $60^{\circ} \mathrm{C}$ & FAM & $99-123$ & 5 & 2.06 & 8 & 3.35 & 7 & 2.89 \\
\hline TGLA126 & 5 & $54{ }^{\circ} \mathrm{C}$ & HEX & $114-128$ & 7 & 3.25 & 7 & 3.40 & 8 & 5.52 \\
\hline BM2113 & 6 & $63^{\circ} \mathrm{C}$ & FAM & $118-146$ & 8 & 6.34 & 9 & 5.90 & 8 & 6.57 \\
\hline ETH10 & 6 & $61{ }^{\circ} \mathrm{C}$ & FAM & $207-225$ & 8 & 5.03 & 7 & 3.99 & 6 & 2.34 \\
\hline ETH225 & 6 & $63^{\circ} \mathrm{C}$ & ATTO550 & $140-162$ & 7 & 2.66 & 8 & 3.38 & 7 & 2.85 \\
\hline INRA023 & 6 & $58^{\circ} \mathrm{C}$ & ATTO550 & 199-219 & 9 & 3.65 & 8 & 2.90 & 7 & 4.79 \\
\hline TGLA122 & 6 & $58^{\circ} \mathrm{C}$ & HEX & $134-174$ & 10 & 3.99 & 8 & 2.56 & 9 & 4.11 \\
\hline Mean & - & - & - & - & 7.11 & 3.97 & 7.41 & 3.62 & 6.74 & 3.79 \\
\hline
\end{tabular}

number of alleles per locus was estimated using GenAlEx 6.503 (Peakall and Smouse, 2012). Deviations of heterozygosities from Hardy-Weinberg equilibrium (HWE) were estimated by (1) calculating the degree of within-population reduction in heterozygosity $\left(F_{\mathrm{IS}}\right)$ following Wright (1951) and permutational test for heterozygosity deficit with jackknifing over loci using FSTAT 2.9.3. Goudet, 2001) and with (2) exact tests of heterozygote excess for each marker and in each breed, as implemented in Genepop (Raymond and Rousset, 1995). The neutrality of the microsatellites used in this study was evaluated by comparing the markers against neutral expectations in a distribution of $F_{\mathrm{ST}}$ vs. heterozygosities under an island model of migration using LOSITAN version 1 (Antao et al., 2008). Pairwise allele sharing distance between populations and inter-individual allele sharing distances were also calculated using MSA. Pairwise interindividual allele sharing distance was utilized to construct the circular tree following neighbor-joining algorithm using PHYLIP version 3.5 (Felsenstein, 1993) and the tree was visualized using MEGA version 6.0 (Tamura et al., 2013). To ascertain the recent history of Niger cattle breeds, prob- abilities of assignment were computed based on likelihood (Paetkau et al., 1995) and Bayesian (Rannala and Mountain, 1997; Baudouin and Lebrun, 2001) methods as implemented in GeneClass 2 software (Piry et al., 2004). The scatter plot of log-likelihood estimates (Baudouin and Lebrun, 2001) for individuals of each of the three Niger cattle breeds was displayed using SPSS version 10.5. The Niger cattle populations were tested for mutation drift equilibrium following three statistical approaches (sign test, standardized differences test and Wilcoxon sign rank test) under different models of microsatellite evolution as implemented in the BOTTLENECK program (Piry et al., 1999).

\section{Results and discussion}

\subsection{Genetic variation in Niger cattle}

A total of 2835 genotypes from 105 animals across $27 \mathrm{mi}-$ crosatellite marker loci were utilized for the present study. The MicroChecker analysis of Niger cattle genotypes at all loci revealed no significant presence of null alleles. In total, 235 alleles were amplified across 27 STR loci in all three 
Table 2. Observed heterozygosity $\left(H_{\mathrm{O}}\right)$, expected heterozygosity $\left(H_{\mathrm{e}}\right)$ and estimated heterozygosity deficit $\left(F_{\mathrm{IS}}\right)$ at different loci in Zebu Arabe, Zebu Bororo and Kuri breeds of Niger cattle.

\begin{tabular}{|c|c|c|c|c|c|c|c|c|c|}
\hline \multirow[t]{2}{*}{ Locus } & \multicolumn{3}{|c|}{ Zebu Arabe } & \multicolumn{3}{|c|}{ Zebu Bororo } & \multicolumn{3}{|c|}{ Kuri } \\
\hline & $H_{\mathrm{O}}$ & $H_{\mathrm{e}}$ & $F_{\mathrm{IS}}$ & $H_{\mathrm{O}}$ & $H_{\mathrm{e}}$ & $F_{\text {IS }}$ & $H_{\mathrm{O}}$ & $H_{\mathrm{e}}$ & $F_{\mathrm{IS}}$ \\
\hline CSRM60 & 0.750 & 0.754 & $0.006^{*}$ & 0.617 & 0.629 & 0.019 & 0.759 & 0.738 & -0.028 \\
\hline CSSM66 & 0.792 & 0.863 & $0.085^{* *}$ & 0.844 & 0.851 & 0.008 & 0.700 & 0.804 & 0.131 \\
\hline HEL1 & 0.731 & 0.705 & -0.037 & 0.565 & 0.679 & 0.169 & 0.700 & 0.729 & 0.04 \\
\hline INRA63 & 0.458 & 0.469 & 0.023 & 0.543 & 0.509 & -0.068 & 0.667 & 0.621 & -0.074 \\
\hline BM1824 & 0.808 & 0.732 & -0.106 & 0.667 & 0.744 & 0.104 & 0.633 & 0.607 & -0.045 \\
\hline ETH152 & 0.538 & 0.578 & 0.069 & 0.563 & 0.587 & 0.042 & 0.633 & 0.563 & -0.127 \\
\hline HAUT27 & 0.481 & 0.649 & 0.262 & 0.702 & 0.741 & 0.053 & 0.379 & 0.629 & $0.401^{* *}$ \\
\hline INRA05 & 0.778 & 0.675 & -0.156 & 0.521 & 0.542 & 0.04 & 0.567 & 0.641 & 0.117 \\
\hline BM1818 & 0.741 & 0.811 & 0.088 & 0.681 & 0.755 & 0.1 & 0.655 & 0.784 & 0.167 \\
\hline ETH3 & 0.593 & 0.689 & 0.142 & 0.417 & 0.468 & 0.111 & 0.643 & 0.662 & 0.029 \\
\hline HEL9 & 0.926 & 0.876 & -0.059 & 0.870 & 0.855 & -0.017 & 0.966 & 0.860 & -0.126 \\
\hline ILSTS006 & 0.852 & 0.728 & -0.174 & 0.745 & 0.712 & -0.047 & 0.621 & 0.626 & 0.009 \\
\hline TGLA53 & 0.769 & 0.812 & 0.054 & 0.771 & 0.789 & 0.023 & 0.793 & 0.844 & 0.061 \\
\hline HAUT24 & 0.815 & 0.843 & 0.035 & 0.625 & 0.765 & 0.185 & 0.700 & 0.794 & 0.12 \\
\hline HEL5 & 0.556 & 0.715 & $0.226^{* *}$ & 0.652 & 0.798 & $0.185^{*}$ & 0.464 & 0.762 & $0.395^{* *}$ \\
\hline INRA032 & 0.778 & 0.853 & 0.089 & 0.813 & 0.821 & 0.011 & 0.800 & 0.776 & -0.031 \\
\hline SPS115 & 0.630 & 0.584 & -0.081 & 0.465 & 0.448 & -0.04 & 0.655 & 0.592 & -0.108 \\
\hline ETH185 & 0.885 & 0.811 & -0.093 & 0.581 & 0.671 & 0.135 & 0.571 & 0.745 & $0.237^{*}$ \\
\hline HEL13 & 0.667 & 0.754 & 0.118 & 0.652 & 0.688 & 0.053 & 0.690 & 0.762 & 0.097 \\
\hline ILSTS05 & 0.692 & 0.717 & 0.035 & 0.694 & 0.745 & 0.068 & 0.700 & 0.735 & 0.048 \\
\hline INRA035 & 0.444 & 0.523 & $0.153^{*}$ & 0.630 & 0.709 & 0.112 & 0.448 & 0.665 & $0.33^{*}$ \\
\hline TGLA126 & 0.704 & 0.705 & 0.002 & 0.689 & 0.714 & 0.036 & 0.967 & 0.833 & -0.164 \\
\hline BM2113 & 0.852 & 0.858 & 0.007 & 0.896 & 0.839 & -0.068 & 0.900 & 0.862 & -0.045 \\
\hline ETH10 & 0.852 & 0.816 & -0.045 & 0.809 & 0.757 & -0.068 & 0.567 & 0.583 & 0.029 \\
\hline ETH225 & 0.556 & 0.636 & 0.128 & 0.708 & 0.711 & 0.004 & 0.733 & 0.660 & -0.112 \\
\hline INRA023 & 0.815 & 0.739 & -0.104 & 0.682 & 0.663 & -0.029 & 0.900 & 0.805 & -0.121 \\
\hline TGLA122 & 0.778 & 0.764 & -0.019 & 0.583 & 0.616 & 0.053 & 0.800 & 0.769 & -0.04 \\
\hline Mean & 0.713 & 0.728 & $0.024^{* *}$ & 0.666 & 0.697 & $0.043^{* *}$ & 0.689 & 0.720 & $0.044^{* *}$ \\
\hline
\end{tabular}

cattle breeds of Niger indicating a high level of allelic diversity. The overall observed number of alleles ranged from 4 (BM1824) to 17 (TGLA53) with a mean of 8.7. Within breeds, the mean observed number of alleles per locus was 7.11, 7.41 and 6.74 in Zebu Arabe, Zebu Bororo and Kuri cattle respectively (Table 1 ). The overall mean observed and expected heterozygosity in Niger cattle was 0.685 and 0.724 respectively. The overall observed heterozygosity ranged from 0.524 (ETH3) to 0.912 (HEL9), while the overall expected heterozygosity varied between 0.533 (SPS115) and 0.869 (HEL9) across the investigated loci. The mean observed heterozygosity was $0.713,0.666$ and 0.689 in Zebu Arabe, Zebu Bororo and Kuri cattle respectively, while the mean expected heterozygosity was estimated to be $0.728,0.697$ and 0.720 respectively (Table 2). Among the three Niger cattle breeds, allelic diversity was highest in Zebu Bororo cattle, while the heterozygosity estimates were observed to be highest in Zebu Arabe cattle. Estimation of effective number of alleles revealed higher values in Zebu Arabe $\left(n_{\mathrm{e}}=3.97\right)$ and Kuri $\left(n_{\mathrm{e}}=3.79\right)$ breeds as compared to Zebu Bororo $\left(n_{\mathrm{e}}=3.62\right)$ cattle. Effective number of alleles is the number of alleles with equal frequencies that would be necessary to achieve the same level of expected heterozygosity $\left(H_{\mathrm{e}}\right)$ in the study population. The values observed in Niger cattle are understandable as the sample size varied across the breeds and low-frequency alleles normally contribute little to the effective number of alleles. Estimates of allelic diversity and heterozygosity in Niger cattle breeds were comparable to those of Cameroonian (Ngono Ema et al., 2014), Senegal (Ndiaye et al., 2015), Sahelian (Alvarez et al., 2014), Sudanese (Hussein et al., 2015), Ethiopian (Dadi et al., 2008) and West and Central African Zebu (Ibeagha-Awamu et al., 2004) cattle. However, these estimates were higher than reported for Mozambican (Bessa et al., 2009), West and Central African taurine cattle (Ibeagha-Awamu et al., 2004). In general, the indigenous cattle breeds of Niger showed high levels of genetic diversity, possibly due to admixture of zebu and taurine 
cattle that had formed the foundation stock of these populations in the past (Dadi et al., 2008).

\subsection{Test for Hardy-Weinberg equilibrium}

The overall mean inbreeding estimate $\left(F_{\text {IS }}\right)$ was 0.051 and it varied between -0.075 (INRA023) and 0.257 (HEL5). The mean inbreeding estimate within breeds was 0.024 , 0.043 and 0.044 in Zebu Arabe, Zebu Bororo and Kuri cattle respectively (Table 2). All three cattle breeds of Niger showed significantly positive mean $F_{\text {IS }}$ indicating moderate heterozygosity deficit. Locus-wise comparison of observed and expected heterozygosity within breeds showed heterozygosity deficit in 17, 20 and 15 loci in Zebu Arabe, Zebu Bororo and Kuri cattle respectively. However, heterozygosity excess was observed in 10,7 and 12 loci in the three breeds respectively. The test for Hardy-Weinberg equilibrium $(\mathrm{HWE})$ revealed significant deviations $(P>0.05)$ for heterozygosity deficiency at 4, 1 and 4 loci in Zebu Arabe, Zebu Bororo and Kuri cattle respectively (Table 2). Of these, locus HEL5 deviated significantly in all three breeds of cattle. A total of 21 out of the 27 investigated loci did not deviate from HWE $(P>0.05)$ in all three cattle breeds studied. HWE test for heterozygosity excess revealed significant deviations in 1 and 2 loci in Zebu Arabe and Kuri cattle respectively. No significant deviations for heterozygosity excess was observed in Zebu Bororo cattle. To summarize, out of 81 breed $\times$ locus combinations tested in Niger cattle, $11.1 \%$ deviated significantly from HWE due to heterozygosity deficit, while $3.7 \%$ deviated significantly due to heterozygosity excess. Departure from HWE due to heterozygosity deficit may result from one or more of the following reasons: (i) presence of null alleles, (ii) intense artificial selection and/or use of few breeding bulls in the region, (iii) selective forces operating at certain loci, (iv) non-random sampling and age structure of samples used, (v) assortative mating, (vi) sex linkage and (vii) Wahlund effect, i.e., presence of fewer heterozygotes in a population than predicted on account of population subdivision (Waples, 2015). The role of null alleles for the observed heterozygosity deficit can be discounted based on the results of MicroChecker analysis. Breeding of native Niger cattle is mostly done through natural service with very low coverage of cows under artificial insemination every year. Selection of animals for improved productivity is rarely practiced and hence reduction in heterozygosity due to intense artificial selection and use of few breeding sires do not arise. Further, the test for selective neutrality following $F_{\text {ST }}$ outlier approach as implemented in LOSITAN revealed no significant deviations in all 27 marker loci investigated. Population subdivision could be one of the possible causes for the observed heterozygosity deficit considering the fact that samples were collected from different geographical locations of the native breed tract. However, it also needs to be mentioned that much higher deviations from HWE have been reported in Brazilian (19.5\% breed $\times$ locus combina-

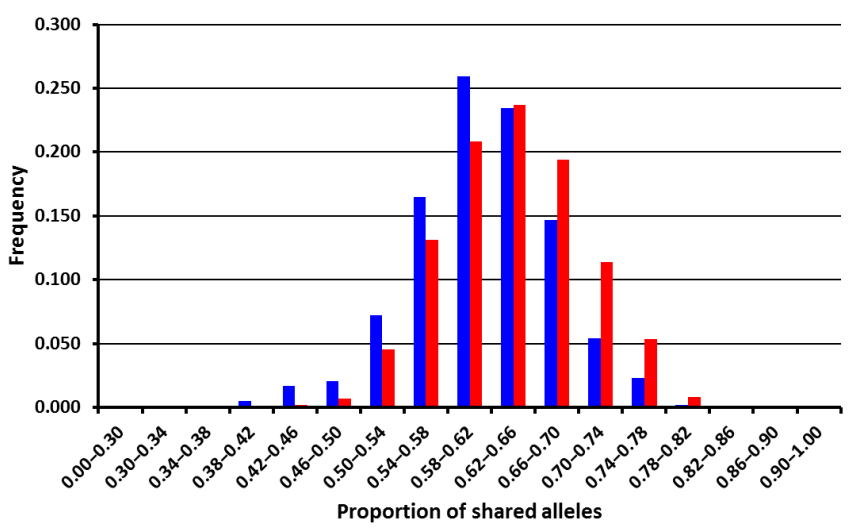

Figure 1. Distribution of allele sharing distance (IBS) between pairs of individuals. Distance was plotted separately where pairs were drawn from within the same breed (blue bars) and from across the breeds (red bars).

Table 3. Pairwise allele sharing distance (lower triangle) and pairwise $F_{\mathrm{ST}}$ (upper triangle) among three Niger cattle breeds.

\begin{tabular}{lrrr}
\hline & Zebu Arabe & Bororo & Kuri \\
\hline Zebu Arabe & - & $0.021^{* *}$ & 0.016 \\
Zebu Bororo & 0.234 & - & $0.035^{* *}$ \\
Kuri & 0.223 & 0.259 & - \\
\hline
\end{tabular}

** $P<0.01$

tions; Egito et al., 2007) and Indian zebu cattle (17.3\% breed $\times$ locus combinations; Sharma et al., 2015).

\subsection{Genetic differentiation among Niger cattle breeds}

The mean global $F_{\mathrm{ST}}$ ranged from -0.003 (BM1818) to 0.166 (ETH3) among different STR loci with an estimated mean value of $0.026(P<0.01)$, indicating $2.6 \%$ of the total variation being attributed to between-breed differences. Although the overall mean global $F_{\mathrm{ST}}$ was significant, 10 out of 27 investigated loci did not have significant $F_{\mathrm{ST}}(P>0.05)$ indicating low genetic differentiation among the Niger cattle breeds. The pairwise $F_{\mathrm{ST}}$ between breeds ranged from 0.016 (Zebu Arabe-Kuri) to 0.035 (Zebu Bororo-Kuri). Similarly, the pairwise allele sharing distance varied from 0.223 (Zebu Arabe-Kuri) to 0.259 (Zebu Bororo-Kuri) (Table 3). The overall $F_{\mathrm{ST}}$ observed in Niger cattle was much lower than that reported for Sudanese $\left(F_{\mathrm{ST}}=0.084\right.$; Hussein et al., $2015)$, Cameroonian $\left(F_{\mathrm{ST}}=0.061\right.$; Ngono Ema et al., 2014) and other West African cattle $\left(F_{\mathrm{ST}}=0.06\right.$; Freeman et al., 2004), while the estimate was relatively higher than that of Ethiopian cattle $\left(F_{\mathrm{ST}}=0.013\right.$; Dadi et al., 2008). Further, to evaluate within- and between-population diversities, pairwise allele sharing distances were calculated for all possible pairs of individuals within and across populations. The average inter-individual distance within breeds was estimated to 
(a)
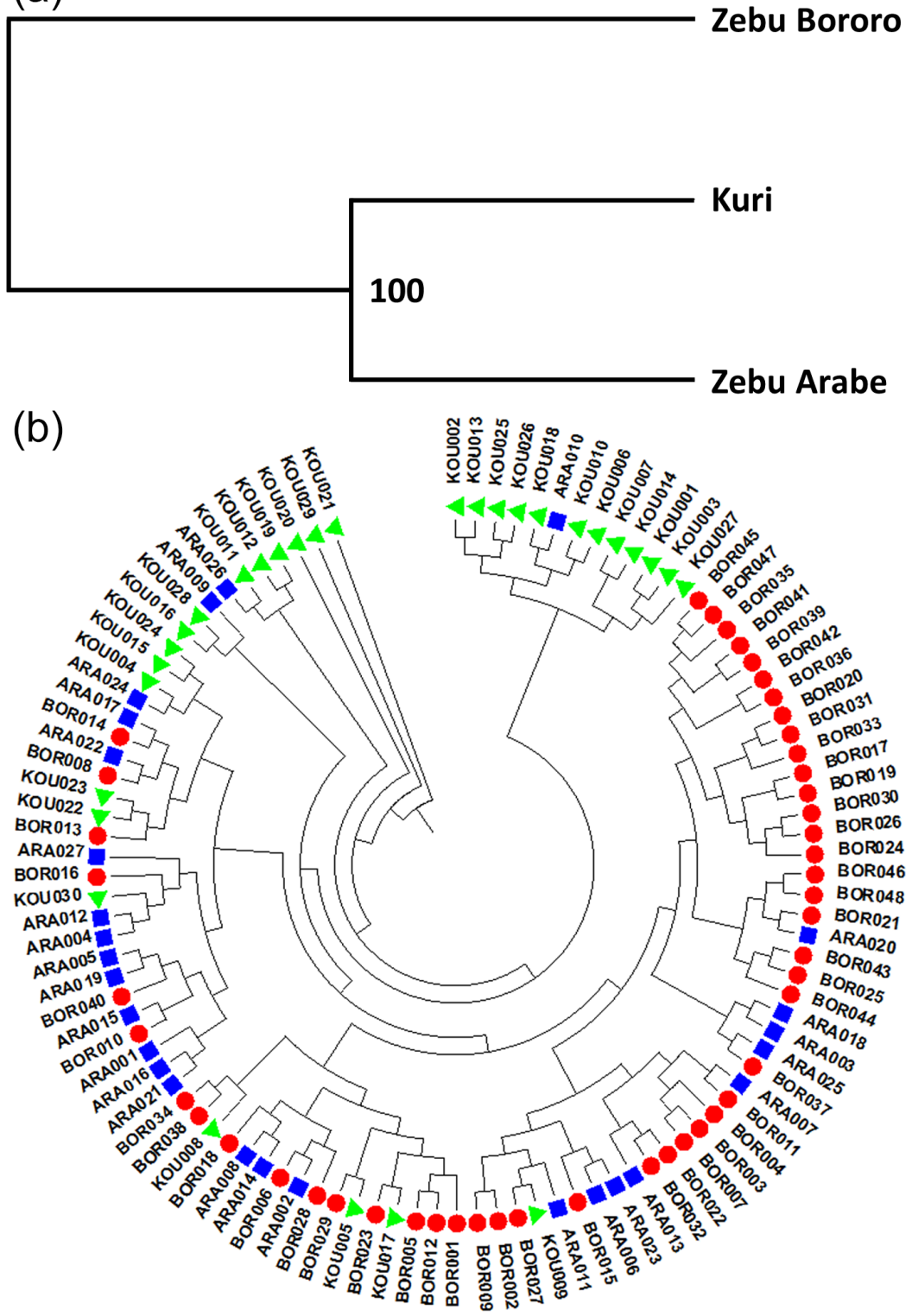

Figure 2. Neighbor-joining tree based on pairwise (a) population and (b) inter-individual allele sharing distances among Zebu Arabe (ARA), Zebu Bororo (BOR) and Kuri (KOU) breeds of Niger cattle (value at the node in a indicates percent bootstrap value out of 1000 resampled subsets of data).

be $0.624,0.601$ and 0.619 in Zebu Arabe, Zebu Bororo and Kuri respectively. The global average distance between individuals drawn from the same population was estimated to be 0.609 , while the average distance between individuals drawn from different populations was estimated to be 0.637 .

The distribution of inter-individual allele sharing distances from within and across populations appeared to be normal (Fig. 1). Further, a large overlap was observed in the distribution of inter-individual distances estimated from within and between breeds indicating that individuals across populations were more related than individuals within populations.
Neighbor-joining tree derived from pairwise allele sharing distance revealed Zebu Arabe and Kuri clustering together, while Zebu Bororo appeared to be relatively distinct from them (Fig. 2a). However, neighbor-joining tree derived from pairwise inter-individual allele sharing distances revealed admixture of individuals from all three breeds, although a subset of individuals from Kuri and Zebu Bororo clustered distinctly (Fig. 2b). This is understandable considering the level of zebu-taurine crossbreeding that has been occurring in the region. Particularly, livestock owners in the region of Lake Chad prefer Kuri $\times$ Zebu crossbred cattle primarily because 
Table 4. Genotype assignment of Zebu Arabe, Zebu Bororo and Kuri breeds of Niger cattle.

\begin{tabular}{lrrr|rr|rr}
\hline Breed & $N$ & \multicolumn{2}{c|}{ Paetkau et al. (1995) } & Rannala and Mountain (1997) & Baudouin and Lebrun (2001) \\
\cline { 3 - 8 } & & $\begin{array}{r}\text { No. correctly } \\
\text { assigned }\end{array}$ & $\begin{array}{r}\text { \% correctly } \\
\text { assigned }\end{array}$ & $\begin{array}{r}\text { No. correctly } \\
\text { assigned }\end{array}$ & $\begin{array}{r}\text { \% correctly } \\
\text { assigned }\end{array}$ & $\begin{array}{r}\text { No. correctly } \\
\text { assigned }\end{array}$ & $\begin{array}{r}\text { correctly } \\
\text { assigned }\end{array}$ \\
\hline Zebu Arabe & 27 & 16 & 59.3 & 19 & 70.4 & 18 & 66.7 \\
Zebu Bororo & 48 & 43 & 89.6 & 42 & 87.5 & 45 & 93.8 \\
Kuri & 30 & 24 & 80.0 & 24 & 80.0 & 25 & 83.3 \\
\hline Total & 105 & 83 & 79.0 & 85 & 81.0 & 88 & 83.8 \\
\hline
\end{tabular}

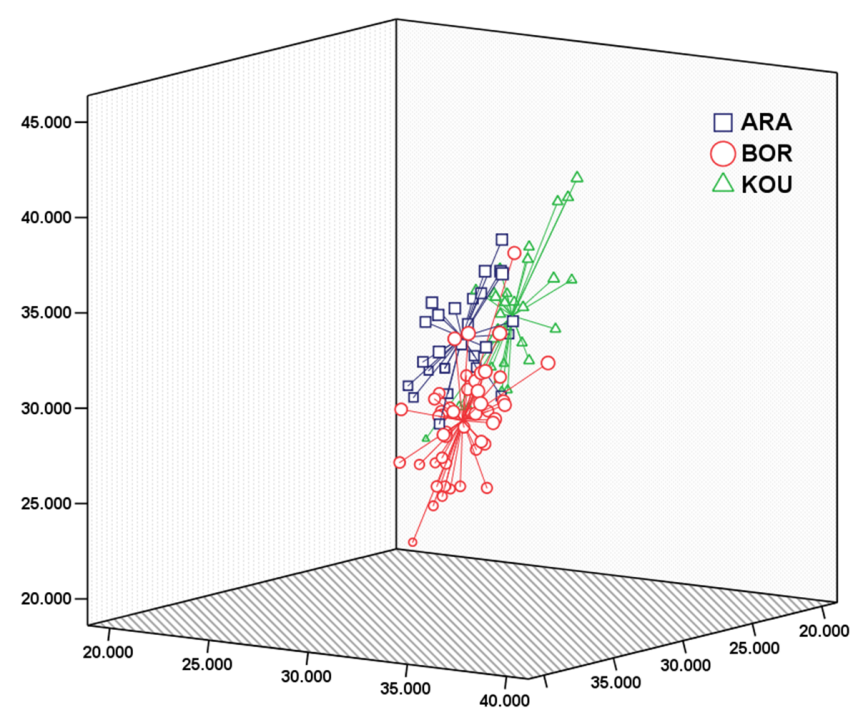

Figure 3. Scatter plot of log-likelihood estimates (Baudouin and Lebrun, 2001) for different individuals of Zebu Arabe (ARA), Zebu Bororo (BOR) and Kuri (KOU) breeds of Niger cattle.

of their large size, relatively higher milk yield, greater fertility and enhanced draught ability. Combined with the reducing habitat due to retreating waters of Lake Chad, Kuri cattle population has declined sharply despite their unique characteristics of being adapted to a semi-aquatic production environment. In case of Zebu Bororo, animals are distributed in a much wider geographical range as compared to Kuri and Zebu Arabe cattle. Clustering of a subset of Zebu Bororo cattle indicates population subdivision; however a larger number of animals needs to be sampled from different regions to confirm the existence of such a cryptic genetic structure.

\subsection{Individual assignment in Niger cattle}

Assignment methods using prior information to ascertain population membership of individuals or groups of individuals have been utilized to assess genetic structure in population genetic studies (Manel et al., 2005). Assignment tests are based on multi-locus genetic data and use both individual genotypes and population-level allele frequencies. In the present study, allele frequencies were utilized to perform genotype assignment based on likelihood and Bayesian methods. The former method calculated the likelihood of drawing a single multi-locus genotype from several potential sources based on the observed allele frequencies at each locus in each source. Genotype assignment following Bayesian procedure involved computation of likelihood of a genotype in a given population under the assumption of equal prior probability density to the allelic frequencies of each locus in each population. This method showed better assignment performance than frequency-based methods in simulated as well as real populations (Cornuet et al., 1999; Arranz et al., 2001; Legaz et al., 2008). Individuals were assigned to their respective source populations, and the percent correct assignment of Zebu Bororo (87.5 to $93.8 \%$ ) was consistently higher than Zebu Arabe (59.3 to $70.4 \%$ ) and Kuri (80.0 to $83.3 \%$ ) cattle across the three evaluated methods (Table 4). Further, plotting of log-likelihood estimates of individual animals in a scattergram revealed overlapping clusters with intermixing of individuals from each of the three cattle breeds (Fig. 3). High levels of admixture in Niger cattle were strongly evident and consistent with the reports on other African cattle (Dadi et al., 2008; Ndiaye et al., 2015). A general point of view is that the $B$. indicus first entered the African continent via the Suez route from Arabia (Epstein and Mason, 1984) and maritime routes to the Horn of Africa (Hanotte et al., 2002). The introduced zebu cattle intermingled and crossbred with the original African taurine to produce the various types of cattle found in East Africa today (Payne and Wilson, 1999). The current breeds/populations of West African zebu (including Zebu Arabe and Zebu Bororo breeds) might have resulted due to migrations of pastoralists from east to west (Clutton-Brock, 1989; Hanotte et al., 2002). The historic gene flow combined with ongoing breeding practices in the region apparently resulted in high levels of admixture among Niger cattle.

\subsection{Test for mutation drift equilibrium}

Populations that have experienced a recent reduction in their effective size exhibit a correlative reduction of allele numbers and gene diversity. For highly variable loci like microsatellites, the rare alleles (alleles with extremely low frequency) 
Table 5. Tests for mutation drift equilibrium in Zebu Arabe, Zebu Bororo and Kuri breeds of Niger cattle.

\begin{tabular}{|c|c|c|c|c|c|c|c|c|c|c|}
\hline \multirow[t]{2}{*}{ Test } & & \multicolumn{3}{|c|}{ Arabe } & \multicolumn{3}{|c|}{ Bororo } & \multicolumn{3}{|c|}{ Kuri } \\
\hline & & IAM & TPM & SMM & IAM & TPM & SMM & IAM & TPM & SMM \\
\hline \multirow[t]{3}{*}{ Sign test } & Expected no. of loci with $H_{\mathrm{e}}$ excess & 16.14 & 16.20 & 16.14 & 16.06 & 16.11 & 15.97 & 16.09 & 16.14 & 16.10 \\
\hline & Observed no. of loci with $H_{\mathrm{e}}$ excess & 15 & 13 & 9 & 16 & 12 & 7 & 18 & 12 & 8 \\
\hline & $P$ value & 0.396 & 0.145 & 0.005 & 0.563 & 0.079 & 0.001 & 0.294 & 0.077 & 0.002 \\
\hline \multirow{2}{*}{$\begin{array}{l}\text { Standardized } \\
\text { differences test }\end{array}$} & $T_{2}$ value & -0.29 & -0.32 & -7.62 & 0.19 & -3.89 & -10.39 & 1.00 & -1.67 & -5.94 \\
\hline & $P$ value & 0.386 & 0.001 & 0.000 & 0.423 & 0.000 & 0.000 & 0.189 & 0.048 & 0.000 \\
\hline $\begin{array}{l}\text { Wilcoxon sign } \\
\text { rank test }\end{array}$ & $P$ value (one tail for $H_{\mathrm{e}}$ excess) & 0.420 & 0.944 & 0.998 & 0.297 & 0.922 & 0.999 & 0.101 & 0.860 & 0.999 \\
\hline
\end{tabular}

are expected to be lost quickly, whereas gene diversity will be lost more slowly. This causes a transient excess of gene diversity after the bottleneck, in comparison to the value expected on the basis of the number of alleles in the population. This temporary genetic signature observed in experimental and wild populations that experienced recent bottleneck events provides a means of detecting recent reductions in effective population size (Shama et al., 2011). Therefore, the reduction in population size (e.g., Kuri) and excess of observed heterozygosity (10, 7 and 12 loci in Zebu Arabe, Zebu Bororo and Kuri cattle respectively) at most of the investigated loci formed the basis to evaluate Niger cattle breeds for mutation drift equilibrium (Kataria et al., 2010; Ganapathi et al., 2012). Niger cattle breeds were subjected to three different statistical tests for mutation drift equilibrium, viz. sign test, Wilcoxon sign rank test and standardized differences test. For each of these tests, three different models of microsatellite evolution - infinite allele model (IAM), stepwise mutation model (SMM) and two-phase model (TPM) - were assumed. All three statistical tests revealed no significant deviation from mutation drift equilibrium, indicating absence of genetic bottleneck in Niger cattle breeds (Table 5). Standardized differences test showed negative $T_{2}$ values for all three breeds under different mutation models (except for Zebu Bororo and Kuri under IAM), clearly indicating the absence of significant heterozygosity excess. In addition, the qualitative method based on mode-shift distortion also showed a normal L-shaped curve in all three Niger cattle breeds (Fig. 4). The frequency distribution of alleles showed abundance of low-frequency alleles (0.001 to 0.1$)$ and no significant loss of rare alleles was observed. Thus, both quantitative and qualitative analysis indicated that the Niger cattle did not experience any genetic bottleneck in the recent past.

\section{Conclusion}

The present study reports high genetic diversity and moderate levels of estimated inbreeding in three important breeds of Niger cattle. The global $F$ statistics showed low genetic differentiation among Niger cattle with about $2.6 \%$ of total (a) Zebu Arabe

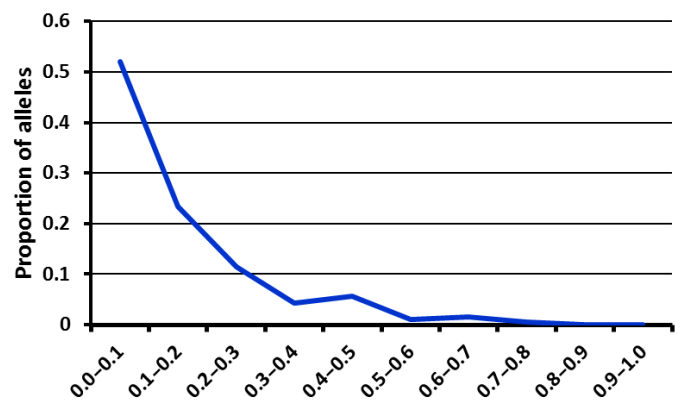

(b) Zebu Bororo

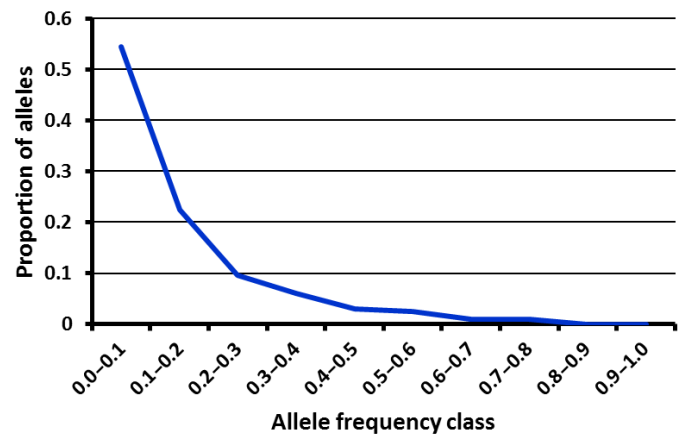

(c) Kuri

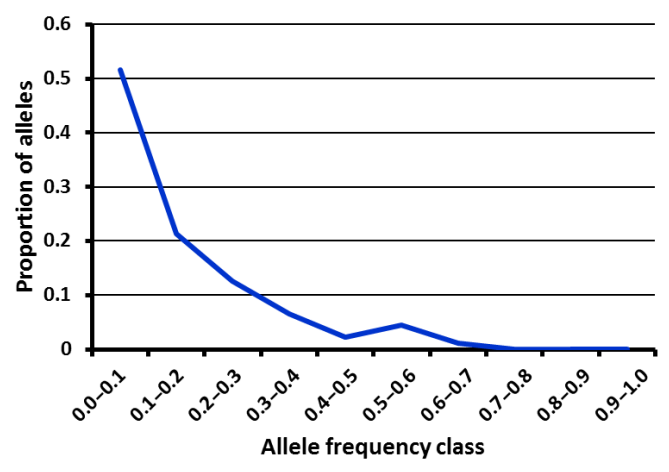

Figure 4. Mode shift analysis showing L-shaped distribution of allele frequencies in (a) Zebu Arabe, (b) Zebu Bororo and (c) Kuri breeds of Niger cattle. 
variation being attributed to between-breed differences. High levels of admixture were evident from the distribution of pairwise inter-individual allele sharing distances that showed individuals across populations being more related than individuals within populations. High genetic diversity and poor genetic structure among indigenous cattle breeds of Niger could be possibly due to historic zebu-taurine admixture and ongoing breeding practices in the region. High rate of gene flow is a cause for concern, particularly in breeds like Kuri where the genetic uniqueness is being lost rapidly. The results of the present study are expected to help in formulating effective strategies for conservation and genetic improvement of indigenous Niger cattle breeds.

Data availability. The original data from the study will be available upon request to the corresponding author.

Author contributions. AT, MI and KP designed the project; MG, MH, MA, HHT and YA collected breed information and samples; MG, MH and MA performed extraction of DNA; MS and RP performed PCR and genotyping; KP, AT, MI and AS performed analysis of data and wrote the manuscript.

Competing interests. The authors declare that they have no conflict of interest.

Acknowledgements. This study was supported by West African Agricultural Productivity Program (WAAPP)-Niger and the Technical Cooperation Project (BKF5017) on "Using Modern Animal Breeding Methods, Nuclear and Genomic Tools to Improve Dairy Production in Smallholder Production Systems" funded by International Atomic Energy Agency. The facilities provided by Institut de l'Environnement et de Recherches Agricoles (INERA), Laboratoire de Biologie et santés animales, Ouagadougou, Burkina Faso, to process blood samples and extract DNA for the study are gratefully acknowledged.

Edited by: Nina Melzer

Reviewed by: Pradeepa Silva and two anonymous referees

\section{References}

Alvarez, I., Traore, A., Fernández, I., Cuervo, M., Lecomte, T., Soudre, A., Kabore, A., Tamboura, H., and Goyache, F.: Assessing introgression of Sahelian zebu genes into native Bos taurus breeds in Burkina Faso, Mol. Biol. Rep., 41, 3745-3754, 2014.

Antao, T., Lopes, A., Lopes, R. J., Beja-Pereira, A., and Luikart, G.: LOSITAN: a workbench to detect molecular adaptation based on a Fst-outlier method, BMC Bioinformatics, 9, 323, 2008.

Apaa-Okello, J., Barry, M., Gueye, C. A., Jack, J., Marchettini, D., Nose, M., Bin Li, G., and Wang, H.: IMF Country Report No. 15/64, International Monetary Fund, Washington
DC, available at: https://www.imf.org/external/pubs/ft/scr/2015/ cr1564.pdf (last access: 15 February 2017), 2015.

Arranz, J. J., Bayón, Y., and San Primitivo, F.: Differentiation among Spanish sheep breeds using microsatellites, Genet. Sel. Evol., 33, 529-542, 2001.

Baudouin, L. and Lebrun, P.: An operational Bayesian approach for the identification of sexually reproduced cross-fertilized populations using molecular markers, Acta Hortic., 546, 81-93, 2001.

Bessa, I., Pinheiro, I., Matola, M., Dzama, K., Rocha, A., and Alexandrino, P.: Genetic diversity and relationships among indigenous Mozambican cattle breeds, S. Afr. J. Anim. Sci., 39, 61-72, 2009.

Blench, C.: Ethno-graphic and linguistic evidence for the prehistory of African ruminant livestock, horses and ponies, in: The Archaeology of Africa: Food, Metals and Towns, edited by: Shaw, T., Sinclair, P., Andah, B., and Okpoko, A., Routledge, London, 71103, 1993.

Clutton-Brock, J.: Cattle in Ancient North Africa, in: The Walking Larder Patterns of Domestication, Pastoralism, and Predation, edited by: Clutton-Brock, J., 200-214, Unwin-Hyman Ltd, London, 1989.

Cornuet, J. M., Piry, S., Luikart, G., Estoup, A., and Solignac, M.: New methods employing multilocus genotypes to select or exclude populations as origins of individuals, Genetics, 153, 19892000, 1999.

Dadi, H., Tibbo, M., Takahashi, Y., Nomura, K., Hanada, H., and Amano, T.: Microsatellite analysis reveals high genetic diversity but low genetic structure in Ethiopian indigenous cattle populations, Anim. Genet., 39, 425-431, 2008.

Dieringer, D. and Schlotterer, C.: MICROSATELLITE ANALYZER (MSA): a platform independent analysis tool for large microsatellite data sets, Mol. Ecol. Notes, 3, 167-169, 2003.

Egito, A. A., Paiva, S. R., Albuquerque, M. S. M., Mariante, A. S., Almeida, L. D., Castro, S. R., and Grattapaglia, D.: Microsatellite based genetic diversity and relationships among ten Creole and commercial cattle breeds raised in Brazil, BMC Genetics, 8, 83, https://doi.org/10.1186/1471-2156-8-83, 2007.

Epstein, H. and Mason, I. L.: Cattle, in: Evolution of Domesticated Animals, edited by: Mason, I. L., 6-27, Longman, New York, 1984.

FAO: Molecular genetic characterization of animal genetic resources, FAO Animal Production and Health Guidelines, No. 9, Rome, 2011.

FAOSTAT: Live Animals, available at: http://faostat.fao.org/ site/573/DesktopDefault.aspx?\#ancor (last access: 13 February 2017), 2014.

Felsenstein, J.: PHYLIP: Phylogeny inference package, version 3.5. Department of Genetics, Washington University, Seattle, Washington, 1993.

Freeman, A. R, Meghen, C. M., MacHugh, D. E., Loftus, R. T., Achukwi, M. D., Bado, A., Sauveroche, B., and Bradley, D. G.: Admixture and diversity in West African cattle populations, Mol. Ecol., 13, 3477-3487, 2004.

Ganapathi, P., Rajendran, R., and Kathiravan, P.: Detection of occurrence of a recent genetic bottleneck event in Indian hill cattle breed Bargur using microsatellite markers, Trop. Anim. Health Pro., 44, 2007-2013, 2012.

Goudet, J.: FSTAT, a program to estimate and test gene diversities and fixation indices (version 2.9.3), available at: http:// 
www2.unil.ch/popgen/softwares/fstat.htm (last access: 7 February 2017), 2001.

Hanotte, O., Bradley, D. G., Ochieng, J. W., Verjee, Y., Hill, E. W., and Rege, J. E. O.: African pastoralism: genetic imprints of origins and migrations, Science, 296, 336-339, 2002.

Hussein, I. H., Alam, S. S., Makkawi, A. A. A., Sid-Ahmed, S. E. A., Abdoon, A. S., and Hassanane, M. S.: Genetic Diversity Between and Within Sudanese Zebu Cattle Breeds Using Microsatellite Markers, Research in Genetics, 2015, 135483, https://doi.org/10.5171/2015.135483, 2015.

Ibeagha-Awemu, E. M., Jann, O. C., Weimann, C., and Erhardt, G.: Genetic diversity, introgression and relationships among West/Central African cattle breeds, Genet. Sel. Evol., 36, 67390, 2004.

Kataria, R. S., Kathiravan, P., Bulandi, S. S., Pandey, D., and Mishra, B. P.: Microsatellite based genetic monitoring to detect cryptic demographic bottleneck in Indian riverine buffaloes (Bubalus bubalis), Trop. Anim. Health Pro., 42, 849-855, 2010.

Legaz, E., Álvarezb, I., Royo, L. J., Fernández, I., Gutiérrez, J. P., and Goyache, F.: Genetic relationships between Spanish Assaf (Assaf.E) and Spanish native dairy sheep breeds, Small Ruminant Res., 80, 39-44, 2008.

Manel, S., Gaggiotti, O. E., and Waples, R. S.: Assignment methods: Matching biological questions with appropriate techniques, Trends Ecol. Evol., 20, 136-142, 2005.

Meghen, C., MacHugh, D. E., and Sauveroche, B.: Characterisation of the Kuri cattle of Lake Chad using molecular genetic techniques, in: Origin and development of African livestock, edited by: Blench, R. M. and MacDonald, K. C., UCL Press, London, UK, 259-268, 2000.

Ndiaye, N. P., Sow, A., Dayo, G. K., Ndiaye, S., Sawadogo, G. J., and Sembène, M.: Genetic diversity and phylogenetic relationships in local cattle breeds of Senegal based on autosomal microsatellite markers, Veterinary World, 8, 994-1005, 2015.

Ngono Ema, P. J., Manjeli, Y., Meutchieyié, F., Keambou, C., Wanjala, B., Desta, A. F., Ommeh, S., Skilton, R., and Djikeng, A.: Genetic diversity of four Cameroonian indigenous cattle using microsatellite markers, Journal of Livestock Science, 5, 9-17, 2014.

Okomo-Adhiambo, M.: Characterization of genetic diversity in indigenous cattle of East Africa: Use of microsatellite DNA techniques, ILRI, Nairobi, Kenya, available at: http://agtr.ilri.cgiar.org/index.php?option=com_content\&task= view\&id=84\&Itemid=101 (last access: 2 February 2017), 2002.

Oosterhout, C. V., Hutchinson, W. F., Wills, D. P. M., and Shipley, P.: MICRO-CHECKER: software for identifying and correcting genotyping errors in microsatellite data, Mol. Ecol. Notes, 4, 535-538, 2004
Paetkau, D., Calvert, W., Sterling, I., and Strobeck, C.: Microsatellite analysis of population structure in Canadian polar bears, Mol. Ecol., 4, 347-354, 1995.

Payne, W. J. A. and Wilson, T. R.: An Introduction to Animal Husbandry in the Tropics, 5th edn., Blackwell Science Ltd, Oxford, 1999.

Peakall, R. and Smouse, P. E.: GenAlEx 6.5: genetic analysis in Excel, Population genetic software for teaching and research-an update, Bioinformatics, 28, 2537-2539, 2012.

Piry, S., Luikart, G., and Cornuet, J. M.: BOTTLENECK: a computer program for detecting recent reductions in the effective population size using allele frequency data, J. Hered., 90, 502503, 1999.

Piry, S., Alapetite, A., Cornuet, J. M., Paetkau, D., Baudouin, L., and Estoup, A.: GeneClass2: A Software for Genetic Assignment and First-Generation Migrant Detection, J. Hered., 95, 536-539, 2004.

Rannala, B. and Mountain, J. L.: Detecting immigration by using multilocus genotypes, P. Natl. Acad. Sci. USA, 94, 9197-9201, 1997.

Raymond, M. and Rousset, F.: GENEPOP (version 1.2): population genetics software for exact tests and ecumenicism, J. Hered., 86, 248-249, 1995.

Shama, L. N. S., Kubow, K. B., Jokela, J., and Robinson, C. T.: Bottlenecks drive temporal and spatial genetic changes in alpine caddisfly meta populations, BMC Evolutionary Biology, 11, 278288, 2011.

Sharma, R., Kishore, A., Mukesh, M., Ahlawat, S., Maitra, A., Pandey, A. K., and Tantia, M. S.: Genetic diversity and relationship of Indian cattle inferred from microsatellite and mitochondrial DNA markers, BMC Genetics, 16, 73, https://doi.org/10.1186/s12863-015-0221-0, 2015.

Tamura, K., Stecher, G., Peterson, D., Filipski, A., and Kumar, S.: MEGA6: Molecular Evolutionary Genetics Analysis Version 6.0, Mol. Biol. Evol., 30, 2725-2729, 2013.

Waples, R. S.: Testing for Hardy-Weinberg proportions: Have we lost the plot?, J. Hered., 106, 1-19, 2015.

World Bank: Livestock in Niger: an important asset for growth and poverty reduction, Livestock Data Innovation in Africa Brief, 86400, 1-2, http://documents. worldbank.org/curated/en/487081468292522854/pdf/ 864000BRI020120Box0385180B00PUBLIC0.pdf (last access: 13 February 2017), 2012.

Wright, S.: The genetical structure of populations, Ann. Eugenic., $15,323-354,1951$. 